\title{
Sick Building Syndrome in Indonesia and Singapore: A Comparative Study
}

\author{
Nia Murniati \\ Hospital Administration Laboratory, Vocational Education Program, Universitas Indonesia \\ *Email: niaboyhadi@yahoo.com
}

\begin{abstract}
Sick Building Syndrome (SBS) occurs due to poor design of buildings. The environment of the building, which is in operation, and the sustenance of the human body are closely related to one another. A building that is designed without focusing on temperature, humidity, airflow, and lighting can lead to sick building syndrome in employees who work in the building (Sick building syndrome, 2011; Anderson, 1990). Convenient use of air conditioning often makes the building manager forget about proper maintenance of air conditioners (AC) and assumes that indoor air from air conditioners is always clean and healthy (Anderson, 1990). Improper AC treatment is likely to spread viruses and bacteria. ${ }^{3}$ This study compares the epidemiology of SBS in Indonesia and Singapore as a developing country and developed country, respectively, in the ASEAN region. The results recorded indicated that the law is not sufficient to suppress the incidence rate of SBS in both countries.
\end{abstract}

Keywords: comparative study, sick building syndrome, non-communicable diseases, auto immune diseases, workers, building

\section{Introduction}

Several discussions are being held on sick building syndrome as a part of the auto immune disease (Sick building syndrome, 2011) A lot of public and private agencies have amassed enormous amounts of information on the disease from toxic air contaminants. As a result, a whole body of law, involving the input of doctors, engineers, environmentalists and sanitation officers, as well as the experts in the quality assurance industry, is being drafted.

Currently, a number of sick building syndromes exist (Anderson, 1990). Sick building syndrome (SBS) is a combination of symptoms that can be associated with exposure to certain building conditions (Occupational diseases and conditions, 2018) Even though office buildings are usually equipped with ventilation or air conditioning systems to create a comfortable working environment, some still showed evidence of sick building syndrome. Temperature, humidity and smoking habits were noted to correlate with SBS. Therefore, it is recommended that the circulation of air is improved to reduce the risk at workplace (Air movement, gender and risk of sick employees in a Jakarta offïce Margaretha Winarti, [Bastaman Basukii, Abdulbar Hamidi (med J indones 2003; 12: 171-7)])

Evidence based on scientific literature and reviewed by different expert groups shows an association between exposure to building dampness and fungal growth and the following respiratory problems: upper respiratory tract symptoms, wheezing, coughing, asthma complaints, and development of new asthma (Karvala, Uitti, Luukkonen \& Nordman, 2013). As developments in building technology continue to change the energy performance of buildings and promote new and innovative building techniques, traditional challenges are addressed and new problems emerge (Zhai, 2016)

\subsection{Sick Building Syndrome}

As defined by the World Health Organization, a sick building syndrome is characterized by an excessive prevalence of irritating symptoms in the skin and mucous membranes of the person who inhabits the building as well as other symptoms such as fatigue, headaches, and difficulty in concentration. Overall evidence suggests that these symptoms are relatively common among office workers. Studies on workers in buildings that were selected without regard to complaints about symptoms reported a prevalence of more than $20 \%$ of at least one work-related symptom (usually defined as a symptom that improves when away from work). Such symptoms can affect employee productivity. A random sample of office workers in the United States showed that at least $20 \%$ reported a decrease in work performance (Bourbeau, Brisson \& Allaire, 1996)

Murphy examines sick building syndrome (SBS), which is defined as a series of complaints from employees (almost always women) that are regarded as sick in certain buildings. Modern office buildings are a complete 
complex consisting of many different and advanced parts of the "things" inside (i.e. fluorescent lamps, air conditioners, carpets, computers, copiers, printers and toners) the building materials. As Murphy noted in the long description of the average chemical composition of office carpets, "by the end of the millennium, building materials will come from Caldas rather than from trees or stones" (Sze, 2007)

The psychosocial climate in the workplace (psychosocial safety climate), measured on the basis of an index of worker dissatisfaction, is associated with common symptoms. Further analysis shows that job satisfaction and cooperation in the work climate, but not stress at work, are related to symptoms. Previous research has shown that psychosocial factors are associated with common symptoms. This is in line with the results of a research on office staff in Denmark, where a psychosocial relationship was found (Norbäck \& Edling, 1991)

The symptoms that arise are associated with unhealthy air inside the building. Complaints encountered in this syndrome include a dry cough, headache, eye irritation, nose and throat issues, dry and itchy skin, weak body, and others. The complaints usually persist for at least two weeks. Though they are usually not too severe, they are quite disturbing and significantly influence one's productivity. The sick building syndrome can only be considered when more than $20 \%$ or even $50 \%$ of the users of a building have complaints as mentioned above; however, when it is limited to only two or three people, it may be due the common cold. SBS complaints can be grouped as follows:

1. Irritation of mucous membranes: eye irritation, sore, red, and watery eyes

2. Nasal irritation: throat irritation, sore swallowing, itching, and dry cough

3. Neurotoxic disorders: headache, weakness or fatigue, irritability, and difficulty concentrating

4. Pulmonary and respiratory disorders: coughs, breathe sounds, shortness of breath, and a sense of heaviness in the chest

5. Skin disorders: dry and itchy skin

6. Gastrointestinal disturbances: diarrhea

7. Other: behavioral disorders, urinary disorders, difficult in learning.

Till date, it is still difficult to determine the only cause of the sick building syndrome, but most of the complaints arising from SBS were caused by air pollution of the rooms. A research by the United States Occupational Safety and Health Agency (NIOSH) on 466 buildings in the United States found that there are six main sources of air pollution in the building. Pollution due to inadequate ventilation in the form of the lack of fresh air entering the building space, uneven air distribution, and poor ventilation maintenance comprised $52 \%$. Air pollution from indoor equipment such as photocopiers, tissue paper, glue paper and wallpaper glue, dye materials from molds, floor cleaners and air freshener formed $17 \%$. Pollution from outside the building can also go into the room; this is due to the precise placement of the location of indoor fresh air entry (11\%). Pollution of building materials including contamination of formaldehyde, glue, asbestos, fiberglass, and other materials that constitute the building's component forms 3\%. Pollution from microbes such as bacteria, fungi, protozoa, and other microbial products that can be found in the airways, refrigerators, and the whole system comprise 5\%, whereas $12 \%$ of the source remained unknown (Saijo, Kishi, Sata, Katakura, Urashima,... Umemura, 2004).

To understand the causes of SBS, efforts have been made to investigate many of the parameters that tend to focus on ventilation performance, contaminants, and various other parameters. Typical parameters that have been investigated include:

1. Ventilation system (Speed of ventilation, too fast or too slow; bad air distribution; inoperative ventilation system; poor air conditioning; bad filtering; and poor treatment).

2. Contaminants of the building (Carbon dioxide, carbon monoxide, dust, formaldehyde, radon, ozone, spores, pollen, bacteria, moisture (too high, too low), ion, smell, smoke, outside pollutants, and organic (volatile) compounds.

3. Occupants age, gender, health status, and occupation.

4. Others (form of building, electromagnetic radiation, lack of environmental control, lighting, noise, and terminal display).

Humans can work comfortably at temperatures of $20-26^{\circ} \mathrm{C}$ and humidity of $40-60 \%$. Room temperature can affect a direct sensory nerve of the mucous membrane and skin and this can have an indirect response on neurosensory functions, resulting in changes in blood circulation. Humidity can affect symptoms of SBS, and there is a significant relationship between dry air, humidity, and temperature, and symptoms of mucous membranes. Chemical pollutants and particles at low humidity may cause dryness and irritation of the eyes, and crowded airways and humidity above $60 \%$ causes fatigue (Saijo et al., 2004)

There are two components of SBS diagnosis: the first is whether the symptoms occur in one or more workers in the same building and the second is a whether symptom appears while one is inside the building and disappears while outside it. Sick building syndrome is not a single disease that can be diagnosed immediately by workers in the building. Asthma, rhinitis and conjunctivitis are allergic diseases that have the same symptoms as SBS. Headache and lethargy are nonspecific symptoms which can occur during severe disease and can be related to occupational exposure. Symptom recognition, physical examination, and laboratory tests when available, are the first steps in the diagnosis of SBS to get rid of other conditions with similar symptoms (Saijo et al., 2004). 
Workers with SBS are more sensitive to stimuli compared to workers without SBS. Wheezing and/or chest complaints are expected to require further examination with peak flow meter or spirometry before and after work. If the results of the examination indicate no abnormalities, then there is no disease. Time of incidence of the disease is an important factor in diagnosing SBS (Saijo et al., 2004).

One of the factors causing SBS is the social environment. The mechanism of environmental stress in the workplace is not yet known, allegedly because there is no balance between needs and abilities. Stress is a combination of the work load in the office and social environment, and this factor can exist as a physiological and psychological phenomenon. Quantity of work can hamper work convenience and contribute to mucosal irritation and other common complaints. These are indirect indicators due to work stress (Saijo et al., 2004).

The best management method is prevention and/ or eliminating the source of contamination or causes of SBS. Patients are encouraged to avoid buildings that can cause complaints even though this is not always practical because it can cause job or productivity loss. Eliminating source pollutants, improving ventilation rate and air distribution, opening the windows before using coolers, keeping clean indoor air, education, and communication, are some ways to overcome SBS (Saijo et al., 2004).

\subsection{Sick Building Syndrome in Indonesia}

The Ministry of Health of the Republic of Indonesia has indicated that many buildings in Indonesia are associated with sick building syndrome.. In these situations, the occupants of the building(s) experience health problems and discomfort due to time spent in the building with regards to poor air ventilation, lighting, ozone emissions from the coffee machine, furniture and wood panel pollution, and cigarette smoke. This situation leads to a decrease in the productivity of the occupants of the building (https://properti.kompas.com/read/2011/02/25/09093018/Banyak.Gedung.Sakit.di.Indonesia).

The housing health problems in Indonesia stem from problems in urban and rural areas. Problems found in urban areas involve quality and quantity of housing. A research on environmental health implemented in West Java mentioned that $59.2 \%$ of the homes studied did not have a good ventilation system and $88.5 \%$ had unqualified building construction. In Indonesia, there has been concern regarding SBS disease: in the annex of OSH Standards, it has been explained that SBS health problems caused by poor indoor quality such as bad ventilation, too low/high humidity, too hot/cold room temperature, dust, mold, air pollutant chemicals, etc. will arise if work, equipment, and work environment are not well designed. A company is obliged to conduct a special health examination, specifically SBS-related examinations for the employee and/ or make changes to the work process, if it discovers exposure to potential health hazards that are of an incidental nature, and the employee should only begin to carry out such work based on the requirement of Minister of Health's Regulation no. 48, 2016 Tentang Standard K3 Perkantoran (Yulianti \& Wiwien, 2012).

Degenerative diseases, as part of non-communicable diseases (NCDs), are a burden that has been caused by the state of health in Indonesia over the past ten years. Despite Indonesia's high morbidity, there are large numbers of urban and rural populations. Hypertension is the most common NCD in Indonesia, with a total prevalence of approximately 31.7\% (Basic Health Research Indonesia, 2007). Other non-communicable diseases of genetic background are stroke (cerebrovascular disease), 8.3\%; heart problems, 7.2\%; cancer and tumor, 4.3\%; asthma, 3.5\%; and diabetes mellitus, $1.1 \%$ (Ministry of Health Republic of Indonesia 2010). Stroke is the most common cause of death; it accounted for $15.4 \%$. Other NCDs that also cause death are hypertension $(6.8 \%)$, ischemic heart disease (5.1\%), and other heart conditions (4.6\%) (Ministry of Public Health Indonesia 2008). NCD is known to have multifactorial etiology. Genomic factors, particularly epigenomics, are believed to play an important role in the development of this condition (Ariani, Soeharso, \& Sjarif, 2017).

\subsection{Sick Building Syndrome in Singapore}

The island city of Singapore is known for many modern office buildings with air conditioning throughout the year. The tropical climate, dense environment, and energy saving requirements present a special limitation for the construction industry to ensure that indoor ventilation and indoor air quality are fully acceptable. Together with the rapid urbanization associated with this new industrial economy, poor health prevention at the office is an increasing challenge for doctors and building managers. In the last decade, there has been an increased awareness of health risks that can occur, accumulate or spread as a result of mechanical ventilation systems. In 1985, the Ministry of Environment started the surveillance program for legionnaire's diseases and the spread of causal bacteria in cooling towers. This was followed in 1992 by the issuance of codes of conduct for use by building owners and management companies in the maintenance and care of cooling towers with air conditioning systems. Other building-related diseases are still being investigated. Although the cause of most building-related symptoms remains unknown, increased dependence on artificial ventilation has caused widespread perception of indoor air pollution as a problem. Sick building syndrome is a major problem because many people may be at risk. It is defined by the World Health Organization (WHO) as an excess of work- 
associated irritation associated on the skin and mucous membranes, and other symptoms including headaches, fatigue and concentration disorders, which allegedly affects workers in modern office buildings. This condition is well documented in temperate countries where it is considered to be a major cause of absenteeism and productivity loss among employees. Because basic data are lacking in the tropics, the national morbidity survey involved 2,856 office workers at 56 randomly selected public and private sector buildings. The goal is to investigate the occurrence of sick building syndrome and its relation to air quality and other factors (Ooi, Goh, Phoon, Foo, \& Yap, 1998).

Singapore has undergone rapid and dramatic demographic and epidemiological changes over the last 40 years. An aging population and increasing number of chronic degenerative diseases such as sick building syndrome have led to higher health demands and hospital costs (Niti \& Ng, 2003).

There is evidence from the 'epidemiologic transition' in chronic degenerative diseases that it will continue to increase even more sharply in the future, due to a strong cohort effect. This is a descriptive study comparing two or more symptoms in different samples. This research focusses on the SBS epidemiology in Indonesia and Singapore, where researchers collected data through various scientific literature and reached conclusions on similarities and differences (Seow, Straughan, Ng, Emmanuel, Tan, \& Lee, 1997).

\section{Results and Discussion}

Regulations in Indonesia such as those relating to air quality and comfort have received considerable attention from the government. This can be seen to range from legislations of a general nature such as constructing buildings to those of a special nature such as the regulation of the minister of health. Legislations related to air quality and air comfort includes UU No. 36 Tahun 2009 tentang Kesehatan, PP No. 50 Tahun 2012 tentang penerapan Manajemen Keselamatan dan Kesehatan Kerja, UU No.28 Tahun 2002 tentang bangunan gedung, PP No. 36 tentang bangunan gedung berkaitan dengan persyaratan kesehatan, PP no. 41 Tahun 1999 tentang pengendalian pencemaran udara, Permenaker No. 13 Tahun 2011 Ambang batas Fisika dan Kimia Tempat Kerja, Keputusan Menaker No. 51 Tahun 1999 tentang Ambang Fisika lingkungan Kerja, Keputusan Menkes No. 14052002 Persyaratan Kesehatan Lingkungan Kerja perkantoran dan Industri, and Keputusan Menkes No.261 Tahun 1998 tentang Kesehatan Lingkungan Kerja. However, the problem of air quality in particular, as in the existing building law, is the health requirements of the building. The health requirements of the building include the requirements of the air conditioning system, lighting, sanitation, and the use of building materials. The ease of the building includes the comfort of space and inter-openness, indoor air conditions, landscape and vibrations, and noise levels. In other legislations, the Government promotes environmental health efforts aimed at realizing a healthy, physical, chemical, biological, and social environmental quality that enables everyone to reach the highest possible level of health. This environment includes neighborhoods, workplaces, recreation areas, and public places and facilities. This healthy environment is free from disruptions that cause health problems, such as wastewater, solids, and gases. The Pasal 163 UU Kesehatan No. 36 Tahun 2009 legislation covers the scope of the workspace; the government seeks to enable worker to live healthy and free from health problems and bad influences caused by work. These occupational health measures involve workers in the formal and informal sectors. They also apply to any person other than the workers in the workplace environment. The government sets the standard of a minimum air space of $10 \mathrm{~m}^{3} / \mathrm{employee}$. Aside the regulations, the government has settled various matters relating to air quality and comfort such as standards on ventilation systems or in-built aeration. This system is a necessity of circulation and air exchange that must be provided in buildings through natural openings and/or mechanical ventilation and/or hybrid (mixed-mode) ventilation. Natural ventilation shall comply with the provisions of permanent openings, gratings on doors and windows, and other means which may be opened, and/or may originate from adjacent rooms to provide healthy air circulation. Mechanical/artificial ventilation should be provided if natural ventilation is not eligible. Based on the principle of energy saving in buildings, the government sets a window area, glass lattice or glass wall for light entry that is at least 1/6 times the floor area. In addition, carriage about the thermal state of the building is also regulated just like stated in Kepmenkes 1405 Tahun 2002 and the regulation of Ministry ESDM Tahun 2005. Like in the ESDM, the thermal conditions of the room are generally set at a temperature of $25^{\circ} \mathrm{C}$ and relative humidity of $60 \%$. At Kepmenkes, the set temperature range is rather wide, between $18-28^{\circ} \mathrm{C}$, with humidity ranging between, $40 \%-60 \%$. The government also regulates the cleanliness of indoor air from harmful elements of health, such as dust and asbestos, comfort of sound (noise), and comfort of view from the outside and inside of buildings. The use of building materials must be safe for the user's health and will not have a negative impact on the environment (Syarif Hidayat, 2017).

The Building and Construction Authority (BCA) has assessed the Third Green Building Master Plan. The new initiatives resulting from this evaluation will be rolled out in phases, to improve the indoor environmental quality for residents, to encourage high energy-efficient buildings, and to make the existing buildings and spaces green. This was announced by the guest of honor, Mr. Desmond Lee, Minister of Social Development and 
Family Development, and the second Minister for National Development, during the opening of the Singapore Green Building Week (SGBW) 2017.

Research by BCA and the National University of Singapore on indoor environmental quality (IEQ) showed that the BCA Green Mark building is not only more energy-efficient, but also offers a healthier indoor climate for the residents. The study notes that residents in Green Mark buildings are more satisfied with their indoor environment and will experience symptoms of sick building syndrome less frequently.

The results of this study help BCA to refine the criteria for the Green Mark scheme in the future. To begin with, BCA is pioneering a new set of criteria for the green mark for existing buildings GM ENRB: a one-year plan for 2017, including improved requirements to build owners to improve IEQ for residents and smart control systems for the operation of the building to use. For example, building owners can use a ventilation strategy that regulates the amount of fresh air input in the building.

In addition, together with the Health Promotion Board (HPB), the BCA is researching a new Green Mark plan to encourage good designs, such as providing energy-efficient lighting and office equipment ("hardware") and the development of the workplace health-related programs ("software") to encourage healthy practices among office staff. The new scheme is intended to allow the company to assess the health and well-being of its residents when designing interior equipment and office requirements, as well as health programs and employee workplace policies.

The Singapore Building and Construction Authority (BCA) defends the development of an excellent environment for Singapore. The BCA's mission is to create a safe, high-quality, sustainable and environmentally friendly environment; these are the four most important elements which BCA influences. BCA therefore intends to distinguish the built-environment of Singapore from other urban environments and to contribute to a better quality of life for everyone in Singapore. That is why its vision is to "have an environment ready for building the future of Singapore." The BCA academy works closely with its educational institution and industrial partners to develop skills and expertise that help shape a future environment for Singapore (Media release SGBW, 2017).

\section{Conclusion}

Indonesia and Singapore are equally well-regulated on the requirements of healthy building. This is evident from various law issued by both countries that protect the workers inside the building. The sick building syndrome figures recorded indicated that the law is not sufficient to suppress the incidence rate of SBS.

\section{Acknowledgments}

I am very grateful to Boy Hadi Ismanto for the necessary collection of literature.

\section{References}

Air movement, gender and risk of sick employees in a Jakarta offïce Margaretha Winarti, [Bastaman Basukii, Abdulbar Hamidi (med J indones 2003; 12: 171-7)]

Anderson, C. (1990). Sick-building syndrome: Suits increase for indoor pollution despite absence of favorable verdict. $A B A$ Journal, 76(12), 17-17. Retrieved from http://remote-lib.ui.ac.id:2098/stable/20761298

Ariani, Y., Soeharso, P., \& Sjarif, D. R. (2017). 10.1002/mgg3.284Molecular Genetics and Genomic Medicine 521031092324-9269 http:https://doi. Organization. Wiley Online Library. doi: 10.1002/mgg3.284

Bourbeau, J., Brisson, C., \& Allaire, S. (1996). Prevalence of the sick building syndrome symptoms in office workers before and after being exposed to a building with an improved ventilation system. Occupational and Environmental Medicine, 53(3), 204-210. Retrieved from http://remote-lib.ui.ac.id:2098/stable/27730513. doi: 10.1136/oem.53.3.204.

Karvala, K., Uitti, J., Luukkonen, R., \& Nordman, H. (2013). Quality of life of patients with asthma related to damp and moldy work environments. Scandinavian Journal of Work, Environment and Health, 39(1), 96-105. Retrieved from http://remote-lib.ui.ac.id:2123/stable/23558266. doi: 10.5271/sjweh.3289.

Media release SGBW (2017)_12 Sept 2017

Niti, M., \& Ng, T. P. (2003). Avoidable hospitalisation rates in Singapore, 1991-1998: Assessing trends and inequities of quality in primary care. Journal of Epidemiology and Community Health,57(1). Retrieved from http://remotelib.ui.ac.id:2123/stable/25569917, (17-22-). doi: 10.1136/jech.57.1.17.

Norbäck, D., \& Edling, C. (1991). Environmental, occupational, and personal factors related to the prevalence of sick building syndrome in the general population. British Journal of Industrial Medicine, 48(7), 451-462. Retrieved from http://remote-lib.ui.ac.id:2098/stable/27727278. doi: 10.1136/oem.48.7.451. 
Occupational diseases and conditions-Sick building syndrome; study data from da yeh university update understanding of sick building syndrome (personal, psychosocial and environmental factors related to sick building syndrome in official employees of Taiwan) (2018, March 23). Health \& Medicine Week. Retrieved from https://remotelib.ui.ac.id:2063/docview/2014725226? accountid=17242

Ooi, P. L., Goh, K. T., Phoon, M. H., Foo, S. C., \& Yap, H. M. (1998). Epidemiology of sick building syndrome and its associated risk factors in Singapore. Occupational and Environmental Medicine, 55(3), 188-193. Retrieved from http://remote-lib.ui.ac.id:2098/stable/27730904. doi: 10.1136/oem.55.3.188.

Retrieved from https://properti.kompas.com/read/2011/02/25/09093018/Banyak.Gedung.Sakit.di.Indonesia

Saijo, Y., Kishi, R., Sata, F., Katakura, Y., Urashima, Y., ... Umemura, T. (2004). Symptoms in relation to chemicals and dampness in newly built dwellings. International Archives of Occupational and Environmental Health, 77(7), 461470. doi: 10.1007/s00420-004-0535-0.

Seow, A., Straughan, P. T., Ng, E. H., Emmanuel, S. C., Tan, C. H., \& Lee, H. P. (1997). Factors determining acceptability of mammography in an Asian population: A study among women in Singapore. Cancer Causes and Control, 8(5), 771-779. Retrieved from http://remote-lib.ui.ac.id:2123/stable/3552786. doi: 10.1023/A:1018439623384.

Sick building syndrome; research from Chaim Sheba Medical Center provides new data about sick building syndrome (2011, September 05). Health \& Medicine Week. Retrieved from https://remotelib.ui.ac.id:2063/docview/886385996?accountid=17242

Syarif Hidayat, Mohd. Tata Loka, 19. NOMOR 1 (February 2017), 15-28 P ISSN. 0852-7458- E ISSN (pp. 2356-0266)

Sze, J. (2007). Sick building syndrome and the problem of uncertainty: environmental politics, technoscience, and women workers. Isis, 98(2), 430-431. doi: 10.1086/521498

Yulianti, M. I., \& Wiwien, H. W. 'Sick Building Syndrome' departemen Pulmonologi dan ilmu Kedokteran Respirasi, fakultas Kedokteran Universitas Indonesia-RS persahabatan, Jakarta: CDK-189/vol.39 No.1 (2012).

Zhai, Z. (2016). Breathing wall: Concept and thermal performance. Cityscape, 18(2), 183-188. Retrieved from http://remotelib.ui.ac.id:2123/stable/26328263 